\title{
Study of correlation of thyroid profile and clinical parameters in patients with infertility
}

\author{
Kameswaramma K.* \\ Department of Obstetrics and Gynecology, Narayana Medical College Hospital, Nellore-524003, Andhra Pradesh, \\ India
}

Received: 08 February 2016

Accepted: 05 March 2016

\section{*Correspondence:}

Dr. Kameswaramma K.,

E-mail: kkameswaramma@ rediffmail.com

Copyright: ( $)$ the author(s), publisher and licensee Medip Academy. This is an open-access article distributed under the terms of the Creative Commons Attribution Non-Commercial License, which permits unrestricted non-commercial use, distribution, and reproduction in any medium, provided the original work is properly cited.

\section{ABSTRACT}

Background: Human infertility is a complex global health problem. It can be divided into two broad categories primary and secondary infertility. Approximately 60-80 million couples suffer from infertility, out of which 15-20 million belong to India. Thyroid dysfunction has a great impact on fertility in women. The present study was carried out to correlate thyroid hormones with infertility in the reproductive age group of women.

Methods: A total of 100 subjects in which 50 infertile women as cases and 50 age matched euthyroid fertile women as controls included in the study. Serum levels of Tetraiodothyronine (T4), Triiodothyronine (T3), and Thyroid stimulation hormone (TSH) were measured by Chemilumeniscence Immunoassay (CLIA). Analysis of variance and Pearson's correlation were used to analyze the data, with the significant p-level set at 0.05 .

Results: Most of the infertile women were having thyroid dysfunction, out of which $20 \%$ were subclinical hyperthyroidism, $6 \%$ overt hyperthyroidism, $12 \%$ subclinical hypothyroidism and $4 \%$ were overt hypothyroidism. Mean serum T3 and T4 were significantly increased $(\mathrm{p}<0.001)$ while TSH levels were significantly decreased $(\mathrm{p}<0.01)$ in hyperthyroid and reverse was happened in hypothyroid cases when compared to controls.

Conclusions: Every infertile woman with ovulatory dysfunction should also investigated thyroid profile along with other investigations, to open better prospects for such desperate infertile women.

Keywords: Thyroid dysfunction, Infertility, Thyroid profile, Subclinical hypothyroidism

\section{INTRODUCTION}

Infertility is a major problem affecting approximately 5$15 \%$ of all married couples. ${ }^{1}$ It is condition with important medical, economic and psychological implications. It can be divided into two broad categories: primary and secondary infertility. Primary infertility refers to the inability to ever have a child. Secondary infertility refers to those cases where people have had children but fail to conceive after that. An average estimate suggests that 60-80 million couples suffer from infertility, out of which 15-20 million couples belong to India. The main causes of female infertility include ovulatory disorders, pelvic inflammatory disease (PID), endometriosis, polycystic ovarian syndrome, advanced age, environmental and occupational exposure to chemicals, congenital abnormalities and hormonal imbalance. ${ }^{2,3}$ Undiagnosed and untreated thyroid disease can be a cause for infertility as well as sub-fertility. Thyroid dysfunction affect fertility in various ways resulting in anovulatory cycles, luteal phase defect, high prolactin (PRL) levels, and sex hormone imbalances.

Prevalence of thyroid dysfunction in the reproductive age group is $2-4 \%$ and has been shown to be the cause of infertility and habitual abortion. Both hypothyroidism and hyperthyroidism are associated with a variety of changes in reproductive functions including delayed onset of puberty, menstrual disorders, anovulatory cycles, infertility and reproductive wastage when pregnancy is achieved. ${ }^{4,5}$ 
Evaluation of thyroid status in the infertile women is not only important because it is significant and most common but also its treatment is very simple and often has reversible or preventable effects on infertility. ${ }^{6,7}$ Data on relationship between subclinical thyroid dysfunction and infertility remain scarce as these subgroups of infertile patients passes unrecognized. Due to the lack of population-based infertility data of women with subclinical thyroid dysfunctions in our state, we planned to evaluate the thyroid status in infertile women.

\section{METHODS}

This is a prospective case control study conducted in the Department of Obstetrics and Gynecology, Narayana Medical College and Hospital, Nellore over a period of 1 year.

After written and informed consent, total 50 infertile women, and 50 normal fertile women volunteers were selected on OPD basis between age group of 19 to 40 years.

Participants were selected on the basis of detailed history, clinical examination and laboratory investigations. Detailed history of participants including age, menstrual history, obstetric history, history of any medications, addictions, was taken.

\section{Inclusion criteria}

- Infertile women age between 20 to 35 years.

- Normal fertile women age between 20 to 35 years.

\section{Exclusion criteria}

- Patient who received medication that could alter TFT (amiodarone an phenytoin excluding $\beta$-blockers, heparin \& dopamine).

- Amongst the female factors were tubal factor, any congenital anomaly of the urogenital tract, or any obvious organic lesion.

- Any history of thyroid disease or previous thyroid surgery.

The study was approved by institutional ethical committee and was conducted after taking informed, written consent of the participants. Venous blood $(5 \mathrm{ml})$ was aseptically collected from the infertile and fertile women by venepunture and dispensed into clean plain bottles, allowed to clot, retracted and centrifuged at 5000 revolution per minute (rpm) for $5 \mathrm{~min}$.

Serum T3 and T4 and TSH analysed by Chemilumeniscence Immunoassay (CLIA) using Acculite CLIA microwells.

\section{Reference values}

Serum T4 - 10.0-28.2pm/L; Serum T3- 4.26-8.10pm/L; Serum TSH $-0.5-5 \mathrm{mU} / \mathrm{ml}$

All the data analysis was performed using SPSS version 17.0 (SPSS inc, Chicago, IL USA). The values were expressed as Mean \pm S.D. Students ' $t$ ' test was used and a $p$ value of $<0.05$ was taken as statistically significant.

\section{RESULTS}

The present study includes 50 infertile women as cases and 50 age matched healthy fertile women as controls. Most of the patients were in the age group of $20-35$ years and the average duration of infertility was 5 years or less. This table shows that there is a highly significant difference in Thyroid profile components in the studied groups $(\mathrm{P}<0.001)$, except FT4. Mean value of FT4 is slightly lower in infertile group than control but difference is not statistically significant. Mean value of TSH is increased in infertile women as compared to control, the difference is highly significant in control \& infertile group $(\mathrm{P}<0.001)$. Comparing primary and secondary infertile group TSH is slightly higher in secondary infertile women; the difference is not statistically significant.

Table 1: Menstrual pattern in study groups.

\begin{tabular}{|lllll|}
\hline Variable & $\begin{array}{l}\text { Primary } \\
\text { infertile } \\
\text { women } \\
(40)\end{array}$ & $\begin{array}{l}\text { Secondary } \\
\text { infertile } \\
\text { women(10) }\end{array}$ & $\begin{array}{l}\text { Control } \\
(50)\end{array}$ \\
\hline Age & $\begin{array}{l}23.525 \pm \\
2.48\end{array}$ & $\begin{array}{l}27.575 \pm \\
1.94\end{array}$ & $\begin{array}{l}27 \pm \\
2.12\end{array}$ \\
\hline Regular & 15 & 3 & 42 \\
\hline Oligomenorrhoea & 17 & 5 & 8 \\
\hline Amenorrhoea & & 15 & 2 & 0 \\
\hline
\end{tabular}

Table 2: Thyroid profile in cases and controls.

\begin{tabular}{|llll|}
\hline Parameter & $\begin{array}{l}\text { Primary } \\
\text { infertile } \\
\text { women } \\
(40)\end{array}$ & $\begin{array}{l}\text { Secondary } \\
\text { infertile } \\
\text { women(10) }\end{array}$ & $\begin{array}{l}\text { Control } \\
(50)\end{array}$ \\
\hline $\begin{array}{l}\text { T3 } \\
(4.26-8.1 \mathrm{pm} / \mathrm{L})\end{array}$ & $6.45 \pm 2.1$ & $6.15 \pm 1.92$ & $7.2 \pm 2.4$ \\
\hline $\begin{array}{l}\text { T4 } \\
(10.0-28.2 \mathrm{pm} / \mathrm{L})\end{array}$ & $23.5 \pm 6.5$ & $22.6 \pm 5.6$ & $24 \pm 5.6$ \\
\hline $\begin{array}{l}\text { TSH } \\
(0.5-5.0 \mathrm{mIU} / \mathrm{L})\end{array}$ & $3.92 \pm 1.9$ & $4.10 \pm 1.8$ & $\begin{array}{l}3.25 \pm \\
1.10\end{array}$ \\
\hline
\end{tabular}

\section{DISCUSSION}

Both subclinical hyperthyroidism and subclinical hypothyroidism are increasingly being recognized as having significant health implications. In both conditions, $\mathrm{T} 3$ and T4 are within the normal reference ranges. Recent 
data indicate that variations of $\mathrm{T} 4$ in the individual are narrower than variations within the reference range for the population.

In current study, there is statistically significant increase in mean serum T3 and T4 and decrease in TSH levels in infertile women when compared to controls. This is in accordance with the report of Singh et al. ${ }^{8}$ prevalence of thyroid dysfunction in infertile women was found to be $23 \%$ in a study by Sharma et al. ${ }^{9}$ In our study, thyroid dysfunction was present in $42 \%$ of the infertile women. Majority of the patients were in euthyroid state which may be due to other cause of infertility.

Significantly higher serum TSH levels were noted in the infertile cases with euthyroid $(\mathrm{p}<0.5)$ and hypothyroidism $(p<0.01)$ when their distributions were compared to their respective control groups. The rise in serum FT4 and FT3 in the infertile group with hyperthyroidism was found to be non-significant as compared to the control group. The prevalence observed as $16 \%$ in our study, $8 \%$ by Goswami et al and $20 \%$ by Sharma et al. ${ }^{9,10}$

The rise in serum FT4 and FT3 in the infertile group with hyperthyroidism was found to be non-significant as compared to the control group with hyperthyroidism.

Hypothyroidism from infancy, if untreated, leads to sexual immaturity and hypothyroidism beginning before puberty causes a delay in onset of puberty followed by anovulatory cycles. It is stated in different textbooks that in adult women, hypothyroidism results in changes in cycle length and amount of bleeding.

Data on the relationship between thyroid disorders and infertility remain scarce and the association with a particular cause of infertility has not been thoroughly analysed. Goswami, study revealed that $62.5 \%$ of hypothyroid cases had menstrual disturbances. ${ }^{10}$ Oligomenorrhoea was observed in $(50 \%)$. In the study done by Krasses et al the prevalence of menstrual irregularities (mainly Oligomenorrhoea) reached $23 \%$ among 171 hypothyroid patients, while being only $8 \%$ in 214 controls $(\mathrm{p}<0.05){ }^{11}$

In this study, the majority of infertile $(77.5 \%)$ as well as fertile $(85 \%)$ women were euthyroid.

Hypothyroidism was more prevalent in the infertile group $(18 \%)$ as compared to control $(7.5 \%)$. The prevalence of hyperthyroidism in the cases and the controls were $4 \%$ and $7.5 \%$, respectively.

Our findings correlates with the study by Goswami et al in their study they investigated women with primary infertility and 80 fertile women with similar age and socioeconomic status were enrolled as the controls. ${ }^{10}$ The incidence of hypothyroidism $(6.4 \%)$ was slightly higher as compared to hyperthyroidism $(4.3 \%)$. These findings of above studies correlate with findings of our study in which we get high prevalence of hypothyroidism in infertile as compared to control. Relatively higher prevalence rate of hypothyroidism in the infertile women found in our study could be due to special referral pattern of the patients who were referred to the hospital based on suspicion of thyroid abnormalities and due to exclusion of other causes of infertility i.e. tubal factor, any congenital anomaly of the urogenital tract, or any obvious organic lesion and male infertility.

In our study we found $16.2 \%$ and $22.5 \%$ hypothyroid women in primary and secondary infertility respectively.

Thyroid hormones receptors are expressed in human oocytes and granulosa cells. At the cellular level, thyroid hormones synergize with the FSH-mediated LH/hCG receptor to exert direct stimulatory effects on granulosa cell function (e.g. progesterone production). Another pathway by which hypothyroidism may impact on fertility is by altering the peripheral metabolism of estrogen and by decreasing SHBG production. Both pathways may result in an abnormal feedback at the pitutary level. Disturbances in normal pulsatile release of LH and hyperprolactinaemia can result in menstrual dysfunction, ranging from anovulatory cycles with menorrhagia, oligomenorrhea or amenorrhea. In a study on Indian women, Joshi et al found $68.2 \%$ of menstrual abnormalities in hypothyroid women compared with $12.2 \%$ of healthy controls. ${ }^{12}$

Thyroid dysfunction is a common cause of infertility which can be easily managed by correcting the appropriate levels of thyroid hormones. The decision to initiate thyroid correction therapy in subclinical thyroid dysfunction at early stage is justified in infertile women. Our data also indicate that variations in TSH levels in the narrower range should not be ignored in infertile women who are otherwise asymptomatic for clinical hyperthyroidism. This group of infertile women, if only carefully diagnosed and treated for hyperthyroidism, can benefit a lot rather than going for unnecessary battery of hormone assays and costly invasive procedures.

\section{CONCLUSION}

Our study reveals that subclinical thyroid dysfunction is more prevalent than overt thyroid dysfunction in infertile women. Hypothyroidism is strongly associated with infertility, than hyperthyroidism. These disorders may lead to menstrual irregularities and anovulation resulting in infertility. The patient may be treated accordingly with medications and can revert back to the fertile state.

Funding: No funding sources

Conflict of interest: None declared

Ethical approval: The study was approved by the Institutional Ethics Committee 


\section{REFERENCES}

1. Sajitha K, Padma SK, Shetty KJ, Kishan Prasad H, Permi HS, Hegde P. Study of histopathological patterns of endometrium in abnormal uterine bleeding. CHRISMED Journal of Health and Research. 2014,1:76.

2. Kamel RM. Management of the infertile couple: an evidence-based protocol. Reproductive Biology and Endocrinology. 2010,8:21.

3. Okonofua FE. Female and male infertility in Nigeria: Studies on the epidemiology of infertility in Nigeria with special reference to the role of genital tract infections and sexual and reproductive risk factors: Institutionen för folkhälsovetenskap/Department of Public Health Sciences; 2005.

4. Thomas R, Reid R. Thyroid disease and reproductive dysfunction: a review. Obstetrics and gynecology. 1987;70:789-98.

5. Melmed S, Polonsky KS, Larsen PR, Kronenberg HM. Williams textbook of endocrinology: Elsevier Health Sciences; 2015.
6. Trokoudes KM, Skordis N, Picolos MK. Infertility and thyroid disorders. Current Opinion in Obstetrics and Gynecology. 2006;18:446-51.

7. Krassas GE. Thyroid disease and female reproduction. Fertility and sterility. 2000;74:106370 .

8. Singh L, Agarwai C, Chowdhary S, Mehra P, Khare R. Thyroid profile in infertile women. 1990.

9. Sharma U, Parmar C. Thyroid profile in infertile women and menstrual dysfunction. Source Indian Medical Gazette, updated 2007.

10. Goswami B, Patel S, Chatterjee M, Koner B, Saxena A. Correlation of prolactin and thyroid hormone concentration with menstrual patterns in infertile women. Journal of Reproduction and Infertility. 2009;10:207-12.

11. Krassas G, Pontikides N, Kaltsas T, Papadopoulou P, Paunkovic J, Paunkovic N, et al. Disturbances of menstruation in hypothyroidism. Clinical endocrinology. 1999;50:655-9.

12. Joshi J, Bhandarkar S, Chadha M, Balaiah D, Shah R. Menstrual irregularities and lactation failure may precede thyroid dysfunction or goitre. Journal of postgraduate medicine. 1993;39:137.

Cite this article as: Kameswaramma K. Study of correlation of thyroid profile and clinical parameters in patients with infertility. Int J Reprod Contracept Obstet Gynecol 2016;5:1410-3. 